\title{
Considering medical missions in all its different forms - a viewpoint from the Asia-Pacific Region
}

\author{
Nyalpi Nungaraia, ${ }^{a, b}$, Matthew Paul ${ }^{a, b}$, Nathan G John ${ }^{a, b}$, Wei-Leong Goh \\ ${ }^{a}$ Medical Doctors from the Asia-Pacific region \\ ${ }^{\mathrm{b}}$ pseudonyms used for security purposes
}

\begin{abstract}
Whereas some medical missionaries may already have moved away from "traditional" models of medical mission, in the experience of the authors from the Asia-Pacific region, many potential medical missionaries in the region still imagine a stereotypical generalist medical missionary who runs a mission hospital.

The authors argue that with the economic and socio-political development of low- and middle-income countries (LMICS) in recent decades, the landscape for medical missions has changed. Hence, contemporary medical missionaries should be well-advised to have specialist qualifications and be more likely to teach, mentor, and do research rather than only doing hands-on clinical work. Professionalism and quality, rather than "make-do," should be the norm. There are more opportunities to partner with and strengthen existing local institutions rather than setting up a Christian health service. Furthermore, mission opportunities may be available in academia, government, or secular organisations, including places where Christianity has a hostile reception. Multi-disciplinary expertise and collaboration within health services are increasingly important and provide another opportunity for missions. Medical missionaries may also come from other LMICs, or from within the same country. Jobsharing, self-funding, or fly-in-fly-out, may be a viable and legitimate means of sending more medical missionaries.

These non-traditional models of medical mission that incorporate a diversity of approaches, but without sacrificing the "traditional" missional values and practices, should allow even more people to serve in medical missions. The purpose of this paper is to survey this topic in hope of stimulating discussions on non-traditional medical mission opportunities in the Asia-Pacific region and beyond.
\end{abstract}

Key Words: Christian mission, low- and middle-income countries, Asia-Pacific Region, healthcare 


\section{Introduction}

Thinking about obstetrics fills me with dread, but how can I learn to do Caesareans because I want to be a missionary doctor?

I'm just a pharmacist, so I guess I need to go to medical school first before I can be useful on the mission field.

I'm planning to go out into the mission field as a doctor as soon as I graduate, and I'll figure it out when I get there.

Should I quit my job as a doctor and serve God full time?

What's the best specialty for me to choose if I want to be a medical missionary?

Why are all the speakers at yet another medical mission event all men, when more than half the audience are female medical students?

These are comments and questions we have heard from committed Christians in the Asia-Pacific region in recent years who are keen to serve the Triune Living God in a cross-cultural context.

These comments and observations highlight for us that for many in our region, the term "missions" is still associated with a romantic and often outdated stereotype. The term "medical missionaries" may still conjure a mental image of white men as "jungle doctors" who joined mission agencies, were self-taught generalists, went to remote "third world" settings, made-do with whatever they had, single-handedly ran a missionhospital, worked all day and all night, learnt how to perform different surgeries (sometimes even from a textbook in the operating theatre), preached the gospel in all spare moments, rarely returned to their home countries, and had a supportive wife who home-schooled their children and quietly taught the Bible to local women.

This may sound antiquated to many readers in the North American context, which continues to send by far the largest numbers of missionaries. ${ }^{1}$

July 2021. Christian Journal for Global Health 8(1)
However, in our own experiences of exploring mission opportunities, being sent out, and talking with our juniors, we have found that this stereotype is often very much alive in the Asia-Pacific region. Hence, when we suggest that it is possible to be a missionary in the form of an academic researcher, a government employee, an allied health professional, or a specialist in a particular field of health, we are often asked "how is that possible?" Those roles may not fit with the traditional missionary stereotype in the minds of many.

The purpose of this article is not to exhaustively review the many complex issues associated with health mission. Rather, we intend to discuss issues that are relevant to Christians in our region who are interested in missions. For each issue, we could give many more examples of people who are involved in non-traditional missions, but for security reasons, we have minimised personal anecdotes.

\section{A Changed State of the World}

Globalisation, industrialisation, migration, and urbanisation have rearranged human geographies and blurred traditional boundaries between missionary sending and receiving countries. This is evident in many of our settings in the Asia-Pacific where there is no longer an obvious axis from the "Christian, developed West" to the "Non-Christian, underdeveloped Third World." Many countries that traditionally received missionaries have undergone tremendous economic development, while countries that were historically Christian are rapidly becoming more secular, with increasing socio-economic inequalities within high- and middle-income countries. National healthcare systems have evolved, imposing stricter standards on all health professionals. Global health continues to grow as a robust field with a corpus of knowledge and best practices. International travel was becoming easier until the pandemic hit, and internet communication 
continues to be become more widespread and convenient. Yet, half of the world's 7.3 billion people continue to experience unmet health needs, ${ }^{2}$ and millions have yet to hear about the Living Triune God.

\section{Non-traditional Sources of Medical}

\section{Missionaries}

As the "West" becomes increasingly postChristian, the centre of gravity of global Christianity has moved to what were traditionally missionsreceiving countries. ${ }^{1,3}$ Therefore, in many low- and middle-income countries (LMICs), the increasing numbers of locally-trained health professionals are likely to be the best source of medical missionaries to the remote, under-developed, and underevangelised regions of the same country. Compared to international missionaries, they have minimal visa requirements, a smaller cultural gap, possibly a smaller language gap, and therefore, may have fewer barriers and a higher probability of effectiveness. Some of these job opportunities for medical missionaries in under-served areas of their own country may even be in government positions (see below). There are also many opportunities for migrants or children of migrants to return to the family's country of origin, where the cultural and linguistic gap may also be smaller. Indeed, in some parts of the world, national graduates of training programmes that were set up by international missionaries are already quietly but faithfully serving their own countries missionally. ${ }^{4}$ For example, South Indians are the biggest source of missionaries to North India, and there are many Indians with overseas citizenship who serve as missionaries in India. ${ }^{5}$

As LMICs develop and churches in those countries mature, those countries will become not only the recipients of missionaries, but they are also likely to send missionaries to other LMICs or even to high-income countries (HICs). ${ }^{1}$ Medical missions and missions in general are no longer characterised by the stereotypical fair-skinned person from a wealthy country serving a dark-skinned person in an impoverished country. Accordingly, the medical missions discourse should revisit its frequent assumptions of what "sending" and "receiving" areas are, acknowledge the growing role of "nonWestern missionaries," and attend to their needs. ${ }^{6}$

\section{Professionalism and Quality}

In the past, when mission hospitals were often the only source of healthcare for large segments of a population, the focus was usually on providing basic and accessible healthcare. They were usually staffed and led by foreign missionaries who provided free or highly subsidized care. As the world has changed rapidly in recent decades, so has this model of traditional mission hospitals and medical missionaries.

Firstly, the model of mission hospitals in the "Third World" financed by Christian patrons in the "West" is now obsolete as many hospitals have nationalized their staffing and management and follow a local financing model. ${ }^{7}$

Secondly, in the past, often the appropriate goal of missionaries was to provide some form of health service where there was none. They made-do with whatever resources were available, and in contemporary healthcare jargon, the focus was on accessibility and not necessarily on quality. In the current era, "making-do" should no longer be the goal when high-quality health services are becoming more common in LMICs; even though such services may be out of reach for many people due to geography or finances, there is an awareness and hence desire for such health services. Furthermore, research has shown that poor quality health services are now responsible for more mortality globally than the lack of access to health services, ${ }^{8}$ therefore, contemporary missions health facilities should not simply provide accessible health services, but they should also aim to provide high-quality health services supported by appropriate clinical 
governance. Establishing and strengthening quality systems is undoubtedly a longer and harder task than for an outsider just to jump in to provide a better service.

Thirdly, with advances in technology and changes in social and cultural values, society's expectations of doctors everywhere are rising. Hence, health systems and health professional education are also changing ${ }^{9}$ and aiming to reach higher standards. ${ }^{10}$ Eight hundred new medical schools started worldwide between 2000 and 2014, ${ }^{11}$ family medicine is a growing medical speciality around the world, ${ }^{12,13,14}$ as are other specialties. Improving the quality of healthcare is on the agenda, ${ }^{15}$ including striving to reach international accreditation standards, ${ }^{16}$ even in low-resource settings. With all these changes, LMICs are justified in being selective about which outsiders they allow to help.

In the past, the stereotypical missionary doctor was a "super-generalist" — a self-taught and competent physician, surgeon, obstetrician, anaesthetist, and paediatrician who treated all conditions while preventing diseases and injuries by running community health programs. However, given the rising patient expectations for specialised care, the rapid expansion of evidence-based medicine, and increased regulations, the self-taught generalist may now be the exception rather than the norm. It is, therefore, most likely that contemporary medical missionaries should expect to undergo standard specialist training in their home countries before going on the mission field, unlike in the past where many missionary doctors often had little more than a basic medical degree and a few years of basic hospital training in their home country. This would mean, for example, a radiation oncologist's mission field would be in an urban teaching hospital, and a missionary with a higher degree in community health would work in a rural area or urban slum.

As specialists, medical missionaries should be expected to maintain their skills and specialist licensing/registration in their home countries, which

July 2021. Christian Journal for Global Health 8(1) requires time and effort. When missionaries eventually return to their home countries for a longer period, up to date specialist licensing/registration should help ensure job prospects. Hence, being on the mission field for many years without returning to the home country may not be viable, and other models of missions need to be considered (see below).

Even if there is an apparently desperate health need, missionaries should not be tempted to rush in to set up a health program without expertise. Bringing in appropriately qualified and experienced personnel to conduct a needs analysis and engaging stakeholders may take longer, but it is now the norm; as is conducting monitoring and evaluation, and there are evidence-based guidelines published for this purpose. ${ }^{17}$ The established and growing discipline of global health ${ }^{18}$ has a corpus of knowledge and best practices. Furthermore, with global information connectivity, the lack of technical soundness in the set-up and implementation of health programmes, and the lack of objective evaluation, even in resource-constrained settings, is no longer excusable. God is not glorified when missionaries have good intentions but bad practice, because this harms Christian witness and may turn people away from Jesus.

The Rt. Rev. Dr. Rowan Williams, when he was the Archbishop of Canterbury, provided a good summary:

The poorest deserve the best [...] They do not deserve what is left over when the more prosperous have had their fill, or what can be patched together on a minimal budget as some sort of damage limitation [...] They deserve it simply because their need is what it is and because where human dignity is least obvious, it's most important to make a fuss about it. ${ }^{19}$ 


\section{Health System Strengthening, not}

\section{Necessarily Service Delivery and}

\section{Substitution}

Traditionally, medical missionaries have been on the front line providing clinical service. As rewarding and tangible as direct service delivery may be, there is always the risk that substituting local health professionals' roles weakens rather than strengthens the long-term capacity of individuals and institutions. Also, health professional licensing/ registration requirements are becoming more stringent in many LMICs, such that foreign health professionals cannot expect just to walk in and do clinical work, and this should generally be seen as a positive phenomenon. With more medical education available in LMICs, ${ }^{11}$ there is less need for foreign professionals to do the job that locals are now trained to do or at least could potentially do.

The contribution of missionaries in the last two centuries who set up medical and nursing schools in "developing countries" or "the colonies" must be acknowledged here. Some of them retain a strong Christian and mission tradition but with minimal input from foreign missionaries (for example, the Christian Medical Colleges of Vellore ${ }^{20}$ and Ludhiana $^{21}$ in India), while others have been appropriately nationalised in other ways. While there may be rare opportunities for missionaries to help set up new teaching institutions in LMICs in the contemporary era, there is an ongoing need for undergraduate and postgraduate health professionals in LMICs to have supervision, training, and mentoring from qualified specialists, both at the undergraduate and post-graduate level. Senior local professionals may not have sufficient capacity to provide the support required, but missionary health professionals may be in a position to offer such a "clinical co-presence." 22

To improve access and quality of healthcare, nurses are also becoming more specialised, even in LMICs. $^{23}$ Therefore, nurses with specialised experience and/or qualifications are more likely to be

July 2021. Christian Journal for Global Health 8(1) needed as teachers, mentors, and consultants on the mission field than in direct clinical service.

While LMICs are rapidly strengthening their capabilities in the established medical specialities of internal medicine, surgery, paediatrics, anaesthetics, obstetrics, and gynaecology, there is an increasingly recognised global need for specialist multidisciplinary care in areas including mental health and psychiatry, ${ }^{24}$ disability and rehabilitation, ${ }^{25}$ and endof-life and palliative care. ${ }^{26}$ Missionary doctors, nurses, and allied health professionals (physiotherapists, pharmacists, psychologists, occupational therapists, etc.) with appropriate advanced training and skills could, therefore, have important roles in teaching and mentoring in these sometimes "hidden" or "difficult" clinical specialities to serve some of the most vulnerable in a community.

Doctors, nurses, and allied health professionals alone cannot be expected to deliver high quality care. Non-clinical professionals including managers, administrators, technicians, engineers, epidemiologists, experts in logistics, procurement, finance, human resources, data management and analysis, information and communication technologies, water and sanitation, and media and communications are also required. They all need to work to a high standard, and they may also have important roles in mentoring ${ }^{27}$ and training-the(local)-trainer ${ }^{28}$ rather than just doing hands-on work.

Other specialised skill competencies that LMICs may require support from external sources include leadership, management, and governance, ${ }^{29}$ teamwork and communication, ${ }^{30}$ quality improvement, ${ }^{31}$ and training the trainer ${ }^{28}$ which are essential elements of modern health systems. Therefore, clinicians with expertise in teaching and implementing these important "soft skills" and technical processes may usefully contribute in a mission context.

Another need in many LMICs is to produce well-conducted research in the local context in order 
to improve health interventions, both at a clinical level and at a population level. In LMICs, research teams and other research infrastructure, such as ethics review boards, may also need external support. ${ }^{32}$ This represents another opportunity for Christians with appropriate qualifications, and likely affiliated with secular research institutes and universities in HICs, to engage in partnerships in LMICs to build health research capacity.

\section{Local Partnerships}

Most LMICs' national health systems, driven by international priorities for primary care and universal health coverage, have extended their health services, even to remote areas. ${ }^{33}$ "Unreached areas" necessitating a medical missionary starting a new health service, are few. Also, with greater regulations in LMICs, opening a new health facility may be difficult for foreigners. Therefore, the more sensible model would be to partner with existing local institutions to enhance their quality and capacity.

The frontline evangelism role of the missionary doctor may also need re-examining, especially where the local church is establishing its witness. The community's insiders fluent in language, culture, and relationships are better positioned to evangelize, and less prone to errors of contextualization or reinforcing a neo-colonial mentality. Furthermore, theologians with advanced academic qualifications may be better placed to teach and mentor Christian leaders, rather than medical missionaries doing it in their spare time with limited theological training.

\section{Academic, Government, Secular Opportunities}

Some of the least evangelized countries or under-served regions within a country can be hostile to overt Christian missions, but remain open to international development assistance or other forms of expatriate expertise, including Christian

July 2021. Christian Journal for Global Health 8(1) professionals from urban areas going to the remote or other under-served regions of the same country. To enter such countries or regions under the auspices of a mission agency as a missionary may be close to impossible, yet those places may welcome highlyqualified health professionals with open arms. Therefore, Christian health professionals may be able to serve in those places through government, academic, or other secular institutions, using the wide variety of skills detailed above. The job may come with an income, and perhaps even a high income, but that should not deter a qualified person with a missionary attitude; a paid job may well come with a greater opportunity to influence, and while there may be some restrictions, there should still be ample opportunity to share the Gospel creatively.

In some places which may not be hostile to Christian work, it may still be wise and strategic for Christians to work in a secular context. For example, rather than setting up an overtly Christian organisation, Christians could join or set up a secular organisation that functions on Christian principles and with Christian leadership. Such settings are likely to provide many opportunities to share the Gospel message through sustained and close interactions with both colleagues and clients.

\section{Self-funding, Job Sharing and Fly-in-Fly- out Options}

The traditional practice of quitting one's job and being financially supported by other Christians to go overseas as a long-term missionary is not the only legitimate mission model. If one has been given the God-given opportunity to have a high earning capacity in one's home country, then perhaps one should not necessarily give up one's job and hope that one's lesser-earning friends will provide the financial support. This may mean working in one's home country for two to three months a year and earning a high income, which is then used to fund unpaid missionary work for the other nine to ten months of the year. For the two to three months each 
year that one returns to one's home country, a colleague could pledge to go to the mission field to provide continuity. This may be a more viable model not only for funding purposes, but also for maintaining connections with family and professional development opportunities.

Other models are also possible, for example, four friends could each pledge to spend three months on the mission field each year.

If missionary professionals are involved in teaching or consultancy roles rather than hands-on roles, then perhaps one may make a long-term commitment to go as a teacher or consultant for six weeks each year, for example. That may be sufficient for some settings, or else, a group of colleagues could each pledge to do the same, so that the receiving institution is guaranteed a regular stream of teachers or consultants throughout the year, and continuous presence is not necessarily required.

With very convenient international travel, these options are feasible compared to many decades ago before air travel, or even just a decade or two ago, before budget airlines. However, we acknowledge that frequent air travel is not environmentally-friendly, or in Christian jargon, caring for God's creation, and should, therefore, be considered carefully and prayerfully.

\section{Feminisation of the Medical Profession}

Female missionaries, especially single women, have always had a prominent role in modern missions, often but certainly not exclusively in nursing. For example, the Christian Medical Colleges of Vellore ${ }^{20}$ and Ludhiana ${ }^{21}$ in India were each founded by a female missionary doctor over a century ago. Often, however, the stereotypical medical missionary is still thought of as male with the trailing wife who raises the children and provides endless hospitality and ministers only to the local women while the husband does all the "official" work. This no longer need be the case, though we do

July 2021. Christian Journal for Global Health 8(1) not disparage the tremendous importance of the countless women in mission fields who have brought great glory to God by faithfully supporting their husbands, providing hospitality, ministering to women, and educating children, often in places where it is inappropriate for women to be employed outside the home. In an era where over 50\% medical students are female in many medical schools around the world and women in professional leadership positions is the norm, in both $\mathrm{HICs}^{34}$ and LMICs, ${ }^{35}$ this should also be expected on the mission field. Highly-qualified professional women can and are becoming missionaries, so young women considering this calling need to be mentored well and not just assumed to be the traditional missionary wife described above.

\section{Don't Forget the Basics - How to be a missionary when your job title is not \\ missionary}

While all these models appear radically different from the traditional model of medical missions, some things should not change. Even if contemporary missionaries may not live in the host country full time for the long term, may not engage in a great deal of hands-on work, and may not work for a Christian organisation, they should still maintain the "traditional" values and practices, with an incarnational approach, including the following:

- Have a genuine commitment to the people and a strong desire to live out the gospel

- Learn some of the local language

- Be immersed in the local culture, for example, in dress

- Remember the poorest and most marginalised (perhaps this is a significant but hidden temptation when the aim is for high-quality rather than make-do)

- Acquire and maintain robust theological knowledge, and have a deep and disciplined spiritual practice 
- Build up locals to work, lead, and minister

- Be a learner and listen to the locals who are experts in their system

- Serve the objectives of the locals and not your own

- Have strong prayer and practical support from friends and family in the home country (and perhaps also from other countries)

\section{Short-term medical missions}

Short-term medical missions have become more common due to the ease of international travel. However, undertaking stand-alone, mission trips that have tenuous connections to long term efforts and "voluntourism" which treats volunteering in vulnerable communities in a voyeuristic manner may bring minimal benefit and even harm, to the hosts. ${ }^{36}$ Therefore, any short-term medical mission efforts should fit into the framework above: a high level of professionalism and quality rather than make-do, partnerships with locals rather than substitution or competition, engaging in non-traditional platforms, maintaining "traditional" values, including longterm commitment with a strong foundation of theology and spirituality. Stand-alone, short-term medical missions or "voluntourism" have no place on the mission field and may even discourage others from approaching the gospel.

\section{Conclusion}

In some settings, the traditional model of medical missions continues to work well, but we need to be aware and acknowledge that their relevance is changing, and that the traditional model may no longer fit many contexts. As the world changes, the opportunities for medical missions are also changing. A certain number of medical missionaries may still be called to work in effective traditional mission settings, but if we insist that is the only way to do "real" medical missions, the

July 2021. Christian Journal for Global Health 8(1) effectiveness of missions will decrease, and opportunities will be missed.

Medical missions must change with the times, but without losing some fundamental values. Medical missionaries may look and work quite differently from their predecessors, but their roles as medical missionaries are just as legitimate, and they deserve and require just as much practical and spiritual support as "traditional" medical missionaries.

We have met young Christian health professionals in the Asia-Pacific region who are very interested in missions, yet they feel that because of their professional interests, their standard training pathways, or their lack of particular training, they cannot be missionaries. Sadly, some resign themselves to a career in the "rat-race" that excludes mission activities; others participate in effective secular global health work without realising this is actually missional and, hence, dichotomise their professional and Christian identities; some may even join more traditional-looking mission activities that have questionable effectiveness or relevance. Therefore, we sincerely hope that by sharing our observations and experiences, we can expand the perspective of what God is doing in His world, so more Christians will be encouraged to use their Godgiven gifts to serve God in non-traditional mission settings.

We hope that our survey of this topic here will stimulate discussion on non-traditional mission opportunities in the Asia-Pacific region and beyond. We are keen to read others' experiences of nontraditional missions globally, as well as any critiques.

\section{References}

1. Johnson TM, Bellofatto GA, Hickman AW, Coon BA, Crossing BF, Krause M, et al. Christianity in its global context, 1970-2020: society, religion and mission [Internet]. Center for the Study of Global Christianity. 2013 [cited 2021 March 5]. Available 
from: https://www.gordonconwell.edu/center-for-

global-christianity/christianity-in-global-context/

2. Tracking universal health coverage: 2017 global

monitoring report [Internet]. World Health

Organization and The World Bank. 2017 [cited 2021

Mar 5]. Available from:

https://www.who.int/healthinfo/universal_health_cov erage/report/2017/en/

3. Tennent C. Invitation to world missions: a trinitarian missiology for the twenty-first century. Grand Rapids: Kregel Publications; 2010.

4. Mettes S. The new faces of medical missions [Internet]. Christianity Today. 2020 Jan 6 [cited 2021 Mar 5]. Available from:

https://www.christianitytoday.com/ct/2020/januaryfebruary/medical-missions-africa-paacs.html

5. Varghese P, editor. On the wings of dawn: medical mission in India today. Chennai: Evangelical Medical Fellowship of India; 2015.

6. O'Donnell K, editor. Doing member care well: perspectives and practices from around the world. Littleton: William Carey Library; 2013.

7. Wood PB. The evolution of church/missions hospitals in Africa. Evangel Missions Q. 2011;47(3):336-40.

8. Kruk ME, Gage AD, Joseph NT, Danaei G, GarcíaSaisó S, Salomon JA. Mortality due to low-quality health systems in the universal health coverage era: a systematic analysis of amenable deaths in 137 countries. Lancet. 2018;392(10160):2203-12. http://doi.org/10.1016/S0140-6736(18)31668-4

9. O'Brien BC, Forrest K, Wijnen-Meijer M, Cate O tenien $\mathrm{BC}$, editors. A global view of structures and trends in medical education. In: Understanding medical education: evidence, theory, and practice, 3rd edition. Edinburgh: The Association for the Study of Medical Education; 2019. p. 7-22. http://doi.org/10.1002/9781119373780

10. Transforming and scaling up health professionals' education and training [Internet]. World Health Organization; 2013 [cited 2021 Mar 5]. Available from:

https://www.who.int/hrh/resources/transf_scaling_hp et/en/

11. Rigby PG, Gururaja RP. World medical schools: the sum also rises. JRSM Open. 2017;

July 2021. Christian Journal for Global Health 8(1)
8(6):2054270417698631. http://doi.org/10.1177/2054270417698631

12. Krztoń-Królewiecka A, Švab I, Oleszczyk M, Seifert B, Smithson WH, Windak A. The development of academic family medicine in central and eastern Europe since 1990. BMC Fam Pract, 2013;14:37. http://doi.org/10.1186/1471-2296-14-37

13. Ng CJ, Teng CL, Abdullah A, Wong CH, Hanafi NS, Phoa SSY et al. The status of family medicine training programs in the Asia Pacific. Family Med. 2016;48:194-202.

14. Flinkenflögel M, Essuman A, Chege P, Ayankogbe $\mathrm{O}$, De Maeseneer J. Family medicine training in subSaharan Africa: South-South cooperation in the Primafamed project as strategy for development. Fam Pract. 2014;31(4): 427-36. http://doi.org/10.1093/fampra/cmu014

15. Nambiar B, Hargreaves DS, Morroni C, Heys M, Crowe S, Pagel C, et al. Improving health-care quality in resource-poor settings. Bull World Health 2017;95:76-8.

16. Smits H, Supachutikul A, Mate KS. Hospital accreditation: lessons from low- and middle-income countries. Glob Health. 2014;10(65). http://doi.org/10.1186/s12992-014-0065-9

17. Lankester $T$, Grills N, editors. Setting up community health and development programmes in low and middle income countries, 4th edition. Oxford: Oxford University Press; 2019.

18. Taylor S. 'Global health': meaning what? BMJ Global Heal. 2018;3:e000843. http://doi.org/10.1136/bmjgh-2018-000843

19. Williams R. Canterbury Sermon [Internet]. 2006 [cited 2021 Mar 5]. Available from: http://news.bbc.co.uk/2/hi/uk_news/6208653.stm

20. Vellore Christian Medical College Foundation, CMC - a historic view [Internet]. [cited 2021 Mar 8].

Available from: https://www.vellorecmc.org/about/introduction-tocmc-vellore/history/

21. Christian Medical College and Hospital, Ludhiana, Our Story [Internet]. [cited 2021 Mar 8]. Available from: https://www.cmcludhiana.in/our-story/

22. Ackers HL, Ackers-Johnson J. 'First do no harm': deploying professional volunteers as knowledge intermediaries. In: Mobile professional voluntarism and international development. New York: Palgrave GLOBAL HEALTH 
Pivot; 2017. Pages 21-50.

http://doi.org/10.1057/978-1-137-55833-6

23. Dawson AJ, Nkowane AM, Whelan A. Approaches to improving the contribution of the nursing and midwifery workforce to increasing universal access to primary health care for vulnerable populations: a systematic review. Hum Resour Health. 2015;13(97).

24. Rehm J, Sheild KD. Global burden of disease and the impact of mental and addictive disorders. Curr Psych Rep. 2019;21(2):10. http://doi.org/10.1007/s11920-019-0997-0

25. World report on disability [Internet]. World Health Organization; 2011 [cited 2021 Mar 5]. Available from:

https://www.who.int/disabilities/world report/2011/r eport/en/

26. Knaul FM, Farmer PE, Krakauer EL, De Lima L, Bhadelia A, Kwete XJ, et al. Alleviating the access abyss in palliative care and pain relief - an imperative of universal health coverage: the Lancet Commission Report. Lancet. 2018;391(10128):1391454. http://doi.org/10.1016/S0140-6736(17)32513-8

27. Lescano AG, Cohen CR, Raj T, Rispel L, Garcia PJ, Zunt JR, et al. Strengthening mentoring in low- and middle-income countries to advance global health research: an overview. Am J Trop Med Hyg. 2019;100(1_Suppl): 3-8. http://doi.org/10.4269/ajtmh.18-0556

28. Mormina M, Pinder, S. A conceptual framework for training of trainers (ToT) interventions in global health. Glob Health. 2018;14(100). http://doi.org/10.1186/s12992-018-0420-3

29. Gilson L, Agyepong IA. Strengthening health system leadership for better governance: what does it take? Health Policy Plann. 2018;33(suppl_2): ii1-ii4. http://doi.org/10.1093/heapol/czy052
30. Scott J, Morales DR, McRitchie A, Riviello R, Smink D, Yule S. Non-technical skills and health care provision in low- and middle-income countries: a systematic review. Med Educ. 2016;50(4):441-55. http://doi.org/10.1111/medu.12939

31. Heiby JR, Armbruster D, Jacobs TA. Better care for every patient, every time: improving quality in lowresource health systems. BJOG. 2014;121(Suppl. 4):4-7. http://doi.org/10.1111/1471-0528.12903

32. Beran D, Byass P, Gbakima A, Kahn K, Sankoh O, Tollman S, et al. Research capacity building obligations for global health partners. Lancet Glob Health. 2017;5(6):E567-E568. http://doi.org/10.1016/S2214-109X(17)30180-8

33. Primary health care on the road to universal health coverage, 2019 global monitoring report [Internet]. World Health Organization, 2019 [cited 2021 Mar 5]. Available from:

https://www.who.int/healthinfo/universal_health_cov erage/report/2019/en/

34. Jefferson L, Bloor K, Maynard A. Women in medicine: historical perspectives and recent trends. Brit Med Bull. 2015;114(1): 5-15. http://doi.org/10.1093/bmb/ldv007

35. Russo G, Gonçalves L, Craveiro I, Dussault G. Feminization of the medical workforce in lowincome settings; findings from surveys in three African capital cities. Hum Resour Health. 2015;13(64). http://doi.org/10.1186/s12960-0150064-9

36. Sykes KJ. Short-term medical service trips: a systematic review of the evidence. Am J Public Health. 2014;104(7): e38-e48. http://doi.org/10.2105/AJPH.2014.301983

Peer Reviewed: Submitted 10 March 2021, accepted 19 May 2021, published 30 July 2021

Competing Interests: All four authors declare that each of us is actively involved in aspects of nontraditional missions, as described in this paper. Note that for reasons of security, pseudonyms were used for the first three authors. Comments or inquiries can be sent to the journal editors.

Cite this article as: Nungarai N, Paul M, John NG, Goh W-L. Considering medical missions in all its different forms - a viewpoint from the Asia-Pacific Region. Christ J Global Health. July 2021; 8(1):4252. https://doi.org/10.15566/cigh.v8i1.523 
(C) Authors. This is an open-access article distributed under the terms of the Creative Commons Attribution License, which permits unrestricted use, distribution, and reproduction in any medium, provided the original author and source are properly cited. To view a copy of the license, visit http://creativecommons.org/licenses/by/4.0/ 